a separate administrative unit of Qing China, when the territorial border between tsarist Russia and China was defined. Since then, this territory has become an arena of confrontation between the two powers for spheres of influence in the Amur Region and Western Manchuria.

This work is devoted to the problems of the history of Hulunbuir from the $17^{\text {th }}$ to the first half of the $20^{\text {th }}$ century. The aim of this work is studying the historical process of the formation of the territorial integrity and national composition of Hulunbuir in the specified period. The author concludes that Hulunbuir is a unique place in China, which should be a separate object of study by the scientific community.

Keywords: Hulunbuir, small nations, Qing period, Russian influence, Republic of China, Manchukuo

УДК 1(031)+221

ЦЫРЕНОВ Чингис Цыбикдоржиевич - кандидат исторических наук, старший научный сотрудник отдела истории и культуры Центральной Азии Института монголоведения, буддологии и тибетологии СО РАН (670047, Россия, Республика Бурятия, г. Улан-Удэ, ул. Сахьяновой, 6; chts17@таil.ru)

\title{
ВТОРОЙ СЕВЕРНЫЙ ПОХОД ГЕНЕРАЛА ВОСТОЧНОЙ ЦЗИНЬ ХУАНЬ ВЭНЯ: ПРИЧИНЫ, ХОД И ПОСЛЕДСТВИЯ
}

\begin{abstract}
Аннотация. В статье кратко рассмотрены сведения о втором северном походе (356 г. н.э.) видного сановника и генерала империи Восточная Цзинь (317-420 гг. н.э.) по имени Хуань Вэнь (312-373 гг. н.э.) против северокитайского цянского мятежного генерала Яо Сяна (331-557 гг. н.э.). В ходе исследования были применены конкретно-исторические методы текстологического, историко-биографического и историко-географического анализа событий и персоналий. Выявлены главные факторы успеха данного похода. Выявлено, что удачный исход второго похода Хуань Вэня был обусловлен стратегическими просчетами его противника Яо Сяна, который фактически оказался в положении ведения войны на два фронта - против Ранней Янь и против Восточной Цзинь - со всеми вытекающими последствиями. В то же время итоги похода не были закреплены из-за фракционной борьбы между столичной (янчжоуской) и региональной (цзинчжоуской) группировками властной элиты Восточной Цзинь, а также общей деградации центрального аппарата власти.
\end{abstract}

Ключевые слова: Восточная Цзинь, Южный Китай, Хуань Вэнь, Ранняя Янь, Лоян, Яо Сян

E сли окинуть взглядом китайскую военную историю, то можно заметить, что походы войск Южного Китая на Север очень редко завершались полным и окончательным успехом. Как правило, более удачными были южные походы северных войск. В XX в. одним из небольших и редких исключений был северный поход Национально-революционной армии в 1926-1927 гг. под руководством Чан Кайши при значительной поддержке КПК и Коминтерна с целью разгрома войск сторонников бэйянской клики.

Что касается военачальника Хуань Вэня, то следует отметить, что он занимает особое место среди государственных деятелей эпохи Восточной Цзинь. Это связано с его успешными походами против северных «варварских государств», которые по ряду причин не были доведены до конца и не привели к возврату северных земель, но все же показали мощь южнокитайской армии раннего Средневековья. Раздробленный север Китая, захваченный кочевыми и полукочевыми этносами, сотрясался от череды дворцовых переворотов, непрерывных военных конфликтов и крестьянских восстаний.

В данной статье мы подробно рассмотрим второй поход Хуань Вэня, направ- 
ленный против генерала-варвара Яо Сяна, который ранее служил северокитайской империи Поздняя Чжао (319-351 гг. н.э.), а после ее распада ненадолго присягнул властям Восточной Цзинь.

Южнокитайская династия Восточная Цзинь занимала южную треть материкового Китая и была преемницей кратковременной всекитайской империи Цзинь (260-317 гг. н.э.), которая в китайской исторической традиции получила название Западная Цзинь. Династии, занимавшие лишь часть территории Поднебесной, было принято называть малым двором в противоположность большому двору всекитайской династии.

Непосредственной причиной распада империи Западная Цзинь стала гражданская война, вызванная мятежом восьми князей правящего клана Сыма (291-306 гг. н.э.), а также последовавшие восстания пяти северных кочевых и полукочевых народов (сюнну, цзе, сяньби, ди и цяны).

Среди отечественных историков-китаеведов, затрагивающих тему второго похода Хуань Вэня, следует прежде всего назвать В.С. Таскина [Материалы по истории... 2012: 203-205], который перевел ряд цзюаней из «Цзиньшу», посвященных вождям кочевых народов Северного Китая эпохи южных и северных царств, создавших собственные династии. Также следует упомянуть российского китаеведа М.Е. Кравцову [История Китая... 2014: 102], а также коллективную монографию «Китайский этнос на пороге средних веков» [Крюков, Малявин, Софронов 1979: 26], где кратко упоминался второй поход Хуань Вэня.

В западной англоязычной научной литературе тему похода Хуань Вэня рассматривал шведский историк-китаевед Ханс Биленштейн [Bielenstein 1996: 75]. В меньшей мере этот вопрос описан у американского историка-китаеведа Чарльза Холкомба [Cambridge History of China 2019], нидерландского синолога Эрика Цюрхера [Zürcher 2007] и др. В китайской исторической литературе XX в. темой похода занимались Тянь Юйцин, Ван Чжунло, Шан Юэ [Tiang Yuqing 2000; Wang Zhongluo 2003; Шан Юэ 1959].

Несмотря на наличие определенного числа отечественных и зарубежных работ по данной тематике, в отечественной синологии существует настоятельная необходимость координации и систематизации базовых историко-биографических и общих фактологических сведений о втором северном походе Хуань Вэня. Особенность данной статьи заключается в том, что автор использовал не переведенные на русский язык фрагменты биографии Хуань Вэня, связанные со вторым северным походом («Цзинь шу», цзюань 98).

При анализе такого сложного и многоаспектного объекта, как геополитика и микроистория Китая эпохи Наньбэй чао, нельзя не использовать историко-биографический и историко-географический методы. Историкобиографический метод известен давно; с ним связано становление и развитие истории как науки, поскольку основным героем политической истории всегда выступала личность - правитель, герой, военачальник и пр. С позиций этого подхода исторический процесс долгое время рассматривался как результат деятельности великих людей ${ }^{1}$.

Источником основных сведений о событиях, связанных со вторым походом Хуань Вэня на Север, является официальная династийная история «История династии Цзинь» («Цзинь шу»), а именно раздел «Цзайцзи» (цзюань 116), и раздел «Лечжуань» (цзюань 98) [Fang Xuanling]. Помимо «Цзинь шу», следует упомянуть об историческом компендиуме «Цзычжи тунцзянь» (раздел «Цзинь Цзи»).

1 Мазур Л.Н. Историко-биографический метод. - Теория и методология исторической науки: терминологический словарь (отв. ред. А.О. Чубарьян). М.: Аквилон. 2014. 576 с. 
Прежде всего необходимо сказать несколько слов о конкретно-историческом и историко-культурном фоне, на основе которого готовился и проходил поход Хуань Вэня. Этот поход был предпринят в период правления малолетнего восточноцзиньского императора Му-ди (личное имя - Сыма Дань, годы жизни 343-361 гг., годы правления 344-361 гг. н.э.), которому на момент второго похода Хуань Вэня было 13 лет, и его регентов (его мать -императрица Чу Суаньцзы из знатного северного клана Чу, 324-384 гг. н.э.; южнокитайский сановник Хэ Чун, 292-346 гг. н.э.; Цай Мо, 281-351 гг. н.э. и позже - Инь Хао, 303-356 гг. н.э).

Все три северных похода генерала Хуань Вэня были проведены по трем различным маршрутам. Маршрут первого северного похода Хуань Вэня состоял из трех частей; его можно условно назвать северо-западным походом. Что же касается второго северного похода Хуань Вэня, то его условно можно обозначить как центральный северный поход, т.к. после форсирования Янцзы в районе Сянъяна Хуань Вэнь пошел не на запад, где находился Чанъань, а в центральный район Китая, где находился город Лоян. Третий северный поход Хуань Вэня можно назвать северо-восточным походом, т.к. исходным пунктом его войск был уже Цзянькан - столичный город Восточной Цзинь.

Рассмотрим более подробно второй поход Восточной Цзинь на север Китая. Он начался в августе 356 г., когда генерал Хуань Вэнь, добившийся присвоения звания великого военачальника (да сыма), выдвинул свои войска из г. Цзянлина в направлении Лояна - столицы двух всекитайских империй прошлого - Поздней Хань и Западной Цзинь. Расстояние между этими городами составляет около 540 км. В биографии Хуань Вэня («Цзиньшу», цзюань 98) описывается ностальгический эпизод, где Хуань Вэнь вспоминает свое раннее детство, проведенное в Северном Китае.

Причиной второго похода Хуань Вэня на север Китая стал мятеж талантливого 26-летнего варварского генерала Яо Сяна (331-557 гг. н.э.), который ранее (в 351 г. н.э.) вместе с отцом и его войсками перешел из распавшегося царства Поздняя Чжао на службу в Цзинь в качестве цзиньского генерала и помощника наместника пограничных областей Се Шана, с которым у него сложились дружеские отношения. Постепенно Яо Сян собрал вокруг себя крупные военные силы и проявил свои военные таланты, что стало причиной зависти Инь Хао нового наместника Цзинь. Из биографии Яо Сяна в «Цзинь шу» (цзюань 116) известно, что Яо Сян был старшим братом Яо Чана - будущего основателя крупного царства Поздняя Цинь. 16 сентября 356 г. войска Хуань Вэня прошли огромный путь в 500 с лишним км, подошли к реке Ишуй (к югу от Лояна) и разгромили войска генерала Яо Сяна. Последний быстро отступил на север и укрылся в г. Пинъяна (юг современной провинции Шэньси). Войска Хуань Вэня не смогли его догнать.

В 357 г. Яо Сян погиб при попытке штурма г. Чанъаня - столицы царства Ранняя Цинь. После разгрома Яо Сяна генерал Хуань Вэнь взял штурмом Лоян, охранявшийся гарнизоном Ранней Цинь. Этот город издавна считался центром Поднебесной. После возврата и реставрации Лояна Хуань Вэнь планировал перенести столицу Восточной Цзинь из южнокитайского Цзянькана на прежнее место. Однако цзяньканский двор отверг это предложение. Помимо захвата Лояна, Хуань Вэнь разгромил целый ряд мятежных командиров и отослал их головы в столицу Восточной Цзинь, а также увел свыше трех тысяч покорившихся семей в свою область Цзинчжоу. За успешную карательную экспедицию против Яо Сяна Хуань Вэнь получил титул наньцзюнь-гуна и постепенно сосредоточил в своих руках власть при дворе Восточной Цзинь.

Под властью Цзинь город Лоян оставался 9 лет, это был первый период пря- 
мого управления Восточной Цзинь городом Лоян. В 364 г. н.э. город был взят войсками сяньбийского царства Ранняя Янь.

Интересно отметить, что основатель КНР Мао Цзэдун, на склоне лет проявивший большой интерес к истории Восточной Цзинь, дал негативную оценку личности Хуань Вэня, т.к. последний, по его словам, пытался узурпировать трон и свергнуть законную династию Восточная Цзинь и правящий дом Сыма [Lu Zhidan 2017: 115].

Таким образом, на основании вышеприведенных конкретно-исторических сведений можно сделать следующие выводы.

Во-первых, успех второго северного похода Хуань Вэня был обусловлен его богатым опытом сражений, а также стратегическими просчетами его противника генерала Яо Сяна, который фактически оказался в положении, когда надо было вести войну на два фронта - против Ранней Янь и против Восточной Цзинь - со всеми вытекающими последствиями.

Во-вторых, военные успехи Хуань Вэня, достигнутые в походах и боях с «варваром» Яо Сяном, с одной стороны, укрепили позиции его клана при дворе Восточной Цзинь и стали символом китайского реванша. Но, с другой стороны, мандат на второй северный поход и его победное завершение стали причиной беспокойства цзяньканского двора. Хуань Вэня стали называть выскочкой, он воспринимался как тиран и узурпатор трона.

В-третьих, необходимо отметить, что из-за межклановых и межсословных противоречий Восточная Цзинь упустила еще один удобный случай вернуть северные земли и воссоздать единую всекитайскую империю. В конечном счете, большая часть плодов победы Хуань Вэня над генералом Яо Сяном в этом походе достались северокитайскому царству Ранняя Янь.

Статья подготовлена в рамках государственного задания (проект «Историческое пространство монгольского мира: археологические культуры, общества и государства»).

\section{Список литературы}

История Китая с древнейших времен до начала XXI века: в 10 т. (гл. ред. С.Л. Тихвинский). Т. ІІІ: Троецарствие, Цзинь, Южные и Северные династии, Суй, Тан (220-907) (отв. ред. И.Ф. Попова, М.Е. Кравцова). 2014. М.: Наука Восточная литература. $991 \mathrm{c.}$

Крюков М.В., Малявин В.В., Софронов М.В. 1979. Китайский этнос на пороге средних веков. М.: Наука. $328 \mathrm{c}$.

Материалы по истории кочевых народов в Китае III-V вв. Вып. 4. Ди и ияны (пер. с кит., предисл. и ком. В.С. Таскина). 2012. М.: Восточная литература. 496 с.

Шан Юэ. 1959. Очерки истории Китая. М.: Восточная литература. 579 с.

Bielenstein H. 1996. The Six Dynasties. Stockholm: MediaPrint, Uddevalla AB. $325 \mathrm{p}$.

Fang Xuanling. Jin shu. Доступ: http://www.guoxue123.com/shibu/0101/00jsj/106. htm (проверено 26.02. 2021).

Lu Zhidan. 2017. (卢志丹). [Суждения Мао Цзэдуна об исторических личноcmax]. Beijing: Renmin ribao chubanshe. 293 p.

The Six Dynasties, 220-589 (ed. by A.E. Dien, K.N.). 2019. - Cambridge History of China. Vol. 2. Knapp. Cambridge University Press. 346 p.

Tian Yuqing 2000. (田余庆). [Режим сановных кланов Восточной Цзинь]. Beijing: Beijing daxue chubanshe. $-374 \mathrm{p}$.

Wang Zhongluo 2003. (王仲華). [История эпохи Вэй-Цзинь и Нань бэй чао]. Shanghai: Shanghai renmin chubanshe. 994 p. 
Zürcher E. 2007. The Buddhist Conquest of China: the Spread and Adaptation of Buddhism in Earlymedieval China (foreword by S.F. Teiser). $3^{\text {rd }}$ ed. Leiden. 472 p.

TSYRENOV Chingis Tsybikdorzhievich, Cand.Sci. (Hist.), Senior Researcher of the Department of history and culture of the Central Asia, Institute for Mongolian, Buddhist and Tibetan Studies, Siberian Branch of the Russian Academy of Sciences (6 Sakhyanovoj St, Ulan-Ude, Republic of Buryatia, Russia, 670047; chts17@mail.ru)

\title{
THE SECOND NORTHERN EXPEDITION OF THE EASTERN JIN GENERAL HUAN WEN: CAUSES, COURSE AND CONSEQUENCES
}

\begin{abstract}
The article briefly reviews the information about the second northern campaign (356 AD) of a prominent dignitary and general of the Eastern Jin Empire (317-420 AD) Huan Wen (312-373 AD) against the North Chinese Qiang rebellious general Yao Xiang. In the course of the study, specific historical methods of textual, historical-biographical and historicalgeographical analysis of events and personalities associated with the second campaign and the corresponding theater of military operations were applied. The main factors for the success of this campaign have been identified. The source of basic information about the events related to the second campaign of Huan Wen to the North is the official dynastic history «History of the [Dynasty] Jin» ("Jin shu»), namely the section "Zaiji» (juan 116) and the section «Liezhuan» (juan 98). As a result of the historical-biographical and historical-geographical analysis of the reviewed information on this campaign, the author reveals that the successful outcome of the second campaign of Huan Wen was due to the strategic mistakes of his enemy general Yao Xiang, who actually found himself in the position of waging a war on two fronts - against the Former Yan and against the Eastern Jin - with all the ensuing consequences. At the same time, the results of the campaign were not fixed due to the factional struggle between the capital (Yangzhou) and regional (Jingzhou) factions of the power elite of the Eastern Jin, as well as the general degradation of the central government system.
\end{abstract}

Keywords: Eastern Jin, South China, Huan Wen, Former Yan, Luoyang, Yao Xiang 